\title{
Strategies Based on Momentum and Term Structure in Financialized Commodity Markets
}

\author{
Adam Zaremba ${ }^{a}$
}

\begin{abstract}
The aim of this paper is to investigate the impact of the financialization of commodity markets on the profitability of strategies based on momentum and term structure. The performance of an array of portfolios from double-sorts on non-commercial traders' participation, historical returns and term spreads are tested against a risk model. The analysis covers the listing of 26 commodities in the period 1986-2013. First and foremost, the paper provides a fresh evidence for the validity of strategies based on momentum and term structure investing in commodity markets. Secondly, it proves that term structure strategies generate significantly higher performance results in non-financialized markets. Moreover, it supports the thesis that market financialization adversely affects momentum profits. The results are important in terms of tactical and strategic asset allocation in commodity markets. They imply that investors who implement momentum or term structure based strategies should also consider the composition of market participants.
\end{abstract}

Keywords: Commodity Futures, Commodity Markets, Financialization, Momentum, Term Structure, Backwardation, Contango, Double-Sort Strategy.

JEL Classification: G11, G13, Q02

\section{Introduction}

Commodity investments have gained huge popularity among investors over the last decade and there are several grounds for their rising recognition as an asset class. Commodities are especially highly valued for the strategic asset allocation, bringing such benefits as long-term equity-like risk premiums (Till, 2007a; Till, 2007b; Till, 2007c; Erb \& Harvey, 2006; Gorton \& Rouvenhorst, 2006), low correlation with other asset classes and diversification properties (Ankrim \& Hensel, 1993; Becker \& Finnerty, 1994; Kaplan i Lummer 1998; Anson ,1999, Jensen, Johnson \& Mercer 2000, Abanomey \& Mathur, 2001; Georgiev, 2001; Gorton \& Rouwenhorst, 2006), hedge against a tail risk (Deaton \& Laroque, 1992; Armstead \& Venkatraman, 2007), positive skewness (Gorton \& Rouwenhorst 2006) and inflation hedging abilities (Erb \& Harvey, 2006; Adams et al., 2008; Zaremba, 2014a).In addition, they provide investors with an easy access exposure to passive and cheap strategies in commodity markets due to the proliferation of ETFs and index products.

Recent research and market practices suggest that commodities are not only useful in terms of strategic asset allocation, but also bring benefits in form of tactical asset allocation within this asset class. Basically, there are two most prominent strategies of achieving abnormal returns in commodity markets.

assist. Prof., Ph.D., Poznan University of Economics, Poznan, Poland, adam.zaremba@ue.poznan.pl 
The first one is a momentum investing strategy, according to which commodities with the highest historical returns outperform the market in the future, while futures with the worst returns underperform the market (Miffre \& Rallis, 2007; Gorton, Hayashi, \& Rouwenhorst, 2013; Fuertes, Miffre \& Rallis, 2010; Fuertes, Miffre \& Fernández-Pérez, 2014). Commodity investors can profit from the momentum effect, for instance, by going long the top performers and shorting the market laggards. The momentum effect was documented in stocks (Jegadeesh \& Titman, 1993; Liew \& Vassalou, 2000; Griffin, Ji, \& Martin, 2003; Chui, Wei, \& Titman, 2010; Fama \& French, 2012;), bonds (Ansess, Moskowitz \& Pedersen, 2013), currencies (Shleifer \& Summers, 1990; Kho, 1996; LeBaron, 1999) and even domestic equity markets (Asness, Liew, \& Stevens, 1997; Bhojraj \& Swaminathan, 2006, Zaremba \& Konieczka, 2014). The profitability of momentum investing strategy in commodity markets is proved in numerous studies (Erb \& Harvey, 2006, Gorton, Hayashi, \& Rouwenhorst, 2013, Miffre \& Rallis, 2007; Gorton, Hayashi, \& Rouwenhorst, 2013; Fuertes, Miffre \& Rallis, 2010; Fuertes, Miffre \& Fernández-Pérez, 2014). Although it is currently one of the most researched phenomenon in the field of finances, no consensus has been reached on the sources of its effectiveness. Possible explanations relate to market microstructure (Osler, 2000), risk management techniques (Garleanu \& Pedersen, 2007) and behavioral biases (Kahneman \& Tversky, 1974; Shefrin, \& Statman, 1985; Froot, Scharfstein, \& Stein 1992; Barberis, Schleifer, \& Vishny, 1998; De Long, Shleifer, Summers, \& Waldmann, 1990; Bikhchandani, Hirshleifer, \& Welch, 1992).

Another well documented strategy is based on a shape of a term structure in commodity markets. The concept underlying this investment technique is related to the hedging pressure hypothesis (Keynes, 1930; Working, 1949; Hirschleifer, 1990; Basu \& Miffre, 2013) which tries to explain the shape of term structure and the source of risk premium in commodity markets. According to this concept, a risk premium is a price of insurance born by market hedgers and transferred to market speculators. If short positions are taken by the majority of hedgers, a downward pressure might be exerted on futures prices, resulting in a downside sloping of a curve. Beneficiaries of such backwardated markets are speculators taking long positions and harvesting risk premiums. On the other side, the prevalence of long speculators in a market might imply a contango situation and result in abnormal returns for speculators taking short positions. A hypothetical investor might benefit from the above described situation, for example, by overweighting commodities with the most downward sloping curves and going short in the most contangoed markets. The validity of such a dynamic approach is proved in numerous studies (De Roon et al., 2000, Erb \& Harvey, 2006; Basu \& Miffre, 2013).

Alas, commodity investments are not flawless despite its earlier status of the Holy Grail of financial markets. What once used to be one of the commodities' greatest advantages might become its doom. The combination of influential publications on the benefits of commodity investing and yield seeking in low rates environment leads to an enormous influx of capital into commodity markets (Tang \& Xiong, 2012; Cheng \& Xiong, 2013). This process is additionally fuelled by the development of electronic trading and the emergence of passive ETFs focused on commodity markets (Irwin \& Sanders, 2012).

Such significant changes result in a structural shift in the composition of market participants. Figure 1 presents the average percentage of reported futures contracts in 26various commodity futures markets held by commercial and non-commercial traders (the latter usually recognized as speculators) over the period 1986 - 2013. The participation of non-commercial traders has increased from $23 \%$ in 1986 to $45 \%$ in 2013 . The growing presence and importance of financial investors in commodity markets is usually referred to as financialization (Domanski \& Heath, 2007). 


\section{Figure 1. Composition of Market Participants in Commodity Markets}

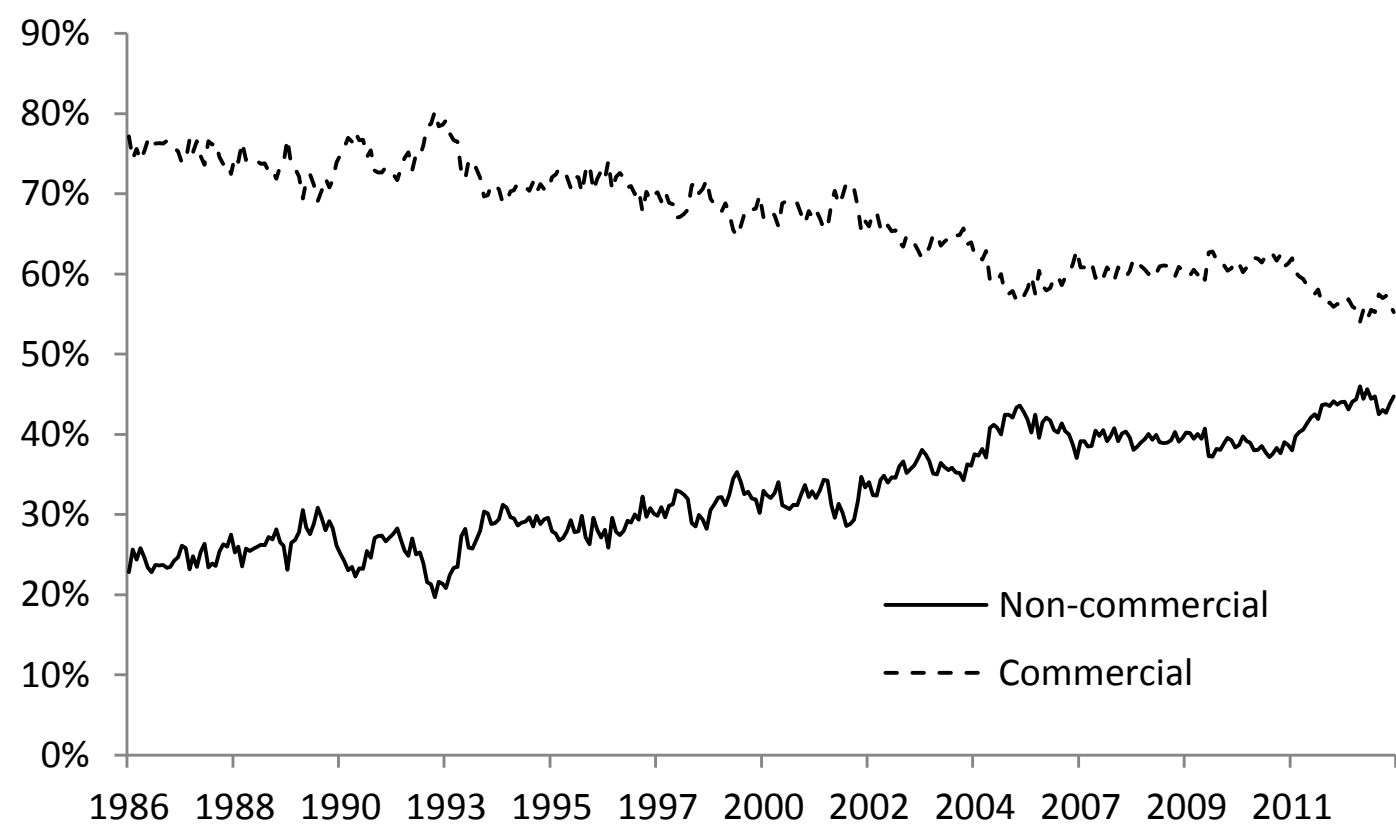

Description: The above figure presents the average relation of open interest held by non-commercial (spread and directional) and commercial market participants to all reportable trades in 26 commodity markets indicated in Table I. Data comes from Bloomberg.

Obviously, the growth of financial investors' presence varies across the markets. Some commodities are financialized more quickly than others. At the end of 2013 non-commercial investors accounted for over half of the open interest on the natural gas market, whereas on the rough rice market only for $20 \%$. Nonetheless, an upward trend generally prevails.

The phenomenon of financialization is said to have brought many changes in commodity markets which, generally, adversely affect investors. Previous studies focused, for instance, on the increase in interasset correlations (Silvennoinen \& Thorp, 2013; Tang\& Xiong, 2012, Zaremba, 2014b), changes in longtermrisk premiums (Mayer, 2010; Tang \& Xiong, 2012; Vdovenko, 2013, Brunetti \& Reiffen, 2011), bubble behavior (Masters, 2008; Gilbert, 2010a; Gilbert, 2010b; Einloth, 2009) or changes in return patterns across business cycles (Zaremba, 2014a). However, a potential impact of financialization on tactical opportunities in commodity markets has not been researched yet ${ }^{1}$.

It can be reasonably presumed that both aforementioned strategies, i.e. momentum and term structure investing, might be affected by the phenomenon of market financialization. First of all, in the case of term structure investing strategy, the greater number of speculators in the market might lead to a decrease in the ratio of speculators to hedgers. This, in turn, might imply a decrease in the risk premium transferred to an average non-commercial market participant. Secondly, a financialization of commodity markets might also impede the profitability of momentum strategies. A growing participation of speculators in the market might coincide with the crowding of momentum investors who, basically follow similar trading signals. This might result in worn out momentum strategies and fading momentum profits.

The primary objective of this paper it to investigate the impact of market financialization on the profitability of term structure and momentum strategies in commodities. The study examines the differentiation of benefits brought by tactical asset allocation in raw materials across markets with various participation level of non-commercial investors. For research purposes double-sorted portfolios are built on the basis of momentum and the shape of a term curve as well as the level of market financialization. Their abnormal returns are tested against a risk model. The analysis covers the listing of 26 commodities in the period $1986-2013$. 
This paper contributes to the academic literature in three ways. First and foremost, it provides a fresh evidence for the validity of strategies based on momentum and term structure investingin commodity markets. Secondly, it proves that term structure strategies generate significantly higher performance results in non-financialized markets. Moreover, it supports the thesis that market financialization adversely affects momentum profits. However, results achieved in the latter case are statistically insignificant.

The structure of this paper is organized as follows: data sources and data preparation are described in Section 2, research methods in Section 3, research findings in Section 4 and conclusions in Section 5.

\section{Data Sources and Initial Preparation}

This paper bases on a set of commodity data obtained from Bloomberg which encompass 26 various types of commodities. Data is diversified accordingly with regard to the type of commodity (agricultural commodities, industrial metals, precious metals and energy) and the type of stock market (Intercontinental Exchange, New York Mercantile Exchange, Chicago Board of Trade and Chicago Mercantile Exchange). Basically, this paper covers the period between January 1986 and December 2013, however, returns are computed only for the period between February 1987 and December 2013. This is due to the fact that older prices are used only in momentum computation. Furthermore, the exact research period differs in certain types of commodities due to the unavailability of data on prices or commitments of traders. The exact research periods for specific types of data are indicated inTable1.

Monthly time series of excess and total returns on commodities are computed on the basis of S\&P$\mathrm{GSCl}$ single commodity excess and total return indices. Where S\&P-GSCl indices are not available, CreditSuisse indices are employed. In other cases, where Credit-Suisse indices lack as well, implemented are JP Morgan and Canadian Imperial Bank of Commerce indicators. All the returns are expressed in US dollars.

The paper investigates the sensitivity of profits resulting from the employment of commodity investing strategies based on momentum and term structure to the financialization of a specific commodity market.

The so called "implied yield" (Fuertes, Miffre \& Rallis, 2013) is used to refer to the shape of a term structure curve. It is calculated in accordance with the following equation:

$$
\mathrm{R}_{\mathrm{t}}=\left[\ln \left(\mathrm{P}_{\mathrm{t}, \mathrm{n}}\right)-\ln \left(\mathrm{P}_{\mathrm{t}, \mathrm{d}}\right)\right] \times \frac{365}{\mathrm{~N}_{\mathrm{t}, \mathrm{d}}-\mathrm{N}_{\mathrm{t}, \mathrm{n}}},
$$

where $P_{t, n}$ is price of the contract with the closest settlement term in the t period of time, $P_{t, d}$ is the price of the contract with the latest settlement date, $\mathrm{N}_{t, n}$ is the number of days between time $t$ and the expiration of the nearest contract and $\mathrm{N}_{\mathrm{t}, \mathrm{d}}$ is the number of days between time $t$ and the expiration of a distant contract. If the price of the nearest contract exceeds the prices of the furthest contract, market is in backwardation and the term structure of commodity futures prices is sloping downwards. On the other hand, an upwards sloping price curve and a contango situation on the market is distinguished by an implied yield lying in its negative zone.

In this paper the implied yield is basically computed on the basis of difference between the prices of contracts with the closest settlement date and the prices of contracts with the second closest settlement date. Additionally, also the differences between the prices pf contracts with the first and the third, as well as the first and the fourth settlement term are computed to test the robustness of results.

Momentum indicator is computed as a one-month excess return for the month preceding the portfolio formation. The methodology used in this paper is consistent with other methods employed in this field of research to take into account the momentum effect (Miffre \& Rallis, 2007; Gorton, Hayashi, \& Rouwenhorst, 2013; Fuertes, Miffre \& Rallis, 2010; Fuertes, Miffre \& Fernández-Pérez, 2014). Basically, all futures are sorted on the basis of one-month returns in the month preceding the portfolio formation. In this case also 3-month and 12-month returns are employed to verify the idiosyncrasy of results to chosen period of sortation. 
Table 1. Commodities Used in the Study

\begin{tabular}{|c|c|c|c|c|c|c|}
\hline \multirow{2}{*}{ Commodity } & \multirow{2}{*}{ Market } & \multirow{2}{*}{ Trading unit } & \multicolumn{2}{|c|}{ CFTC data } & \multicolumn{2}{|c|}{ Price data } \\
\hline & & & Start date & End date & Start date & End date \\
\hline Brent Crude Oil & NYMEX & 1.000 barrels & $2011-10-18$ & $2013-12-31$ & 1999-01-31 & $2013-12-31$ \\
\hline Cocoa & ICE & 10 metric tons & 2007-09-04 & $2013-12-31$ & 1986-01-31 & 2013-12-31 \\
\hline Coffee & ICE & 37.500 pounds & 2007-09-04 & $2013-12-31$ & 1986-01-31 & 2013-12-31 \\
\hline Copper & COMEX & 25.000 pounds & 1989-07-31 & $2013-12-31$ & 1986-01-31 & 2013-12-31 \\
\hline Corn & СВОТ & 1.000 bushels & 1986-01-15 & $2013-12-31$ & 1986-01-31 & 2013-12-31 \\
\hline Cotton & ICE & 50.000 pounds & 2007-09-04 & $2013-12-31$ & 1986-01-31 & 2013-12-31 \\
\hline Ethanol & СВOT & 29.000 U.S. gallons & 2009-11-03 & $2013-12-31$ & $2008-12-31$ & 2013-12-31 \\
\hline Feeder Cattle & COMEX & 50.000 pounds & 1986-01-15 & $2013-12-31$ & $2002-01-31$ & 2013-12-31 \\
\hline Gasoline & NYMEX & 42.000 U.S. gallons & $2006-02-14$ & 2013-12-31 & 1988-01-31 & 2013-12-31 \\
\hline Gold & COMEX & 100 troy ounces & $1986-01-15$ & 2013-12-31 & 1986-01-31 & 2013-12-31 \\
\hline Heating Oil & NYMEX & 42.000 U.S. gallons & $1986-01-15$ & $2013-12-31$ & 1986-01-31 & 2013-12-31 \\
\hline Lean Hogs & COMEX & 40.000 pounds & 1996-04-02 & 2013-12-31 & 1986-01-31 & 2013-12-31 \\
\hline Live Cattle & COMEX & 40.000 pounds & 1986-01-15 & $2013-12-31$ & 1986-01-31 & 2013-12-31 \\
\hline Natural Gas & NYMEX & 10,000 MMBTU'S & 1990-04-12 & $2013-12-31$ & 1994-01-31 & 2013-12-31 \\
\hline Oats & СВОТ & 1.000 bushels & 1986-01-15 & $2013-12-31$ & 1998-01-31 & 2013-12-31 \\
\hline Orange Juice & ICE & 15.000 pounds & 2007-09-04 & $2013-12-31$ & 1998-01-31 & 2013-12-31 \\
\hline Palladium & NYMEX & 101 troy ounces & 1986-01-15 & 2013-12-31 & 1995-01-31 & 2013-12-31 \\
\hline Platinum & NYMEX & 5.000 troy ounces & 1986-01-15 & 2013-12-31 & 1986-01-31 & 2013-12-31 \\
\hline Rough Rice & СВОТ & 200.000 pounds & 1994-10-04 & 2013-12-31 & 1998-01-31 & 2013-12-31 \\
\hline Silver & COMEX & 50 troy ounces & 1986-01-15 & $2013-12-31$ & 1986-01-31 & 2013-12-31 \\
\hline Soybean Meal & СВОТ & 11 metric tons & 1986-01-15 & $2013-12-31$ & $2004-12-31$ & 2013-12-31 \\
\hline Soybean Oil & СВОТ & 60.000 pounds & 1986-01-15 & $2013-12-31$ & 2005-01-31 & 2013-12-31 \\
\hline Soybeans & СBOT & 1.000 bushels & 1986-01-15 & $2013-12-31$ & 1986-01-31 & 2013-12-31 \\
\hline Sugar & ICE & 112.000 pounds & 2007-09-04 & 2013-12-31 & 1986-01-31 & 2013-12-31 \\
\hline Wheat & СBOT & 1.000 bushels & 1986-01-15 & $2013-12-10$ & 1986-01-31 & 2013-12-31 \\
\hline WTI Crude Oil & NYMEX & 1.000 barrels & 2006-07-11 & 2013-09-17 & 1987-01-31 & 2013-12-31 \\
\hline
\end{tabular}

Description: NYMEX - New York Mercantile Exchange, ICE - Intercontinental Exchange, CBOT-Chicago Board of Trade, COMEX - Chicago Mercantile Exchange.

Finally, the last variable in this research is market financialization. The basic aim of this variable is to measure the share of the futures market which is held by non-financial participants. The greater is this share, the stronger is the financialization. As there are almost none common and broadly accepted measures of the level of financialization in commodity markets ${ }^{2}$, this paper put forwards a new definition. The cross-sectional impact of market financialization level might influence rates of returns. The level of market financialization is measured with the ratio of futures positions held by non-commercial investors (including spread investors) to all reported positions:

$$
\operatorname{fin}_{\mathrm{t}}=\frac{\mathrm{NCNL}_{\mathrm{t}}+\mathrm{NCNS}_{\mathrm{t}}+\mathrm{SPR}_{\mathrm{t}}}{\mathrm{TR}_{\mathrm{t}}}
$$

where $\mathrm{fin}_{\mathrm{t}}$ is the level of financialization, $N C N L_{t}, N C N S_{t}, \mathrm{SPR}_{t}$ are non-commercial long, non-commercial short and spread positions, correspondingly. $T R_{t}$ is the number of all reported positions. The data source is the US Commodity Futures Trading Commission. In the case of returns in month $t$ the data obtained at the end of a preceding month is used. In the rest of the text, by "high financialization" or "finacialized market" I will mean the situation when the ratio in formula (2) is high or above average, contrary to "low financialization" or "non-financialized market". 


\section{Research Methodology}

In order to measure an impact of market financialization on returns to yield and momentum strategies, the performance of an array of single- and double-sorted portfolios is tested.

Single-sorted portfolios are based on momentum and time structure strategies. In terms of momentum, futures in the research sample are initially divided into two momentum portfolios based on their historical performance. The breakpoint of momentum is defined as the median historical return of all futures in the sample in a given month. It is worth pointing out that in the majority of cross-sectional research studies financial instruments are grouped into decile or quintile portfolios. However, the median was implemented as the only breakpoint to avoid any small-sample bias as commodity futures market is not as big as, for instance, stock market. Next, futures are classified into high-momentum and low-momentum subgroups, and equal-weighted to form portfolios. Finally, fully collateralized long and short portfolios are created. The portfolios are long in the equally weighted portfolio of high momentum futures, short in the portfolio of low momentum futures and fully collateralized in risk-free assets. A one-month LIBOR USD is employed as a proxy for risk-free returns.

A term structure strategy is analogical to the one described above, however, futures are sorted in accordance with their implied yield. The final long and short portfolios take long positions in contracts with the highest implied yields and short positions in futures with the lowest yields. It is important to note that portfolio formation procedure is indifferent to the situation in the market, regardless of its backwardation or contango. What matters is only a relative position of an implied yield in relation to other futures, not its actual sign.

The next step consists in the comparison of single-sorted portfolios with double-sorted one. In this case, contracts are additionally sorted according to their financialization level at the end of the month preceding the portfolio formation. Once again the breakpoint is defined as the median level, thus, commodities are divided into two subgroups. Simultaneously, term structure and momentum breakpoints are intersected with financialization breakpoints. In consequence, there are four double-sorts on momentum and financialization and four double-sorts on term structure and financialization. Based on this, there are eight equally weighted double-sorted portfolios constructed. Then, to assess the performance of momentum and term structure strategies in financialized and non-financialized markets, there are long and short momentum portfolios constructed within the subgroups of financialized and non-financialized markets. In other words, four long and short portfolios are formed on the basis of double-sorts: long and short term structure strategy in markets of high financialization, long and short term structure strategy in markets of low financialization, long and short momentum strategy in markets of high financialization as well as long and short momentum strategy in markets of low financialization. Similarly to the cases of single-sorted strategies, all portfolios are fully collateralized in risk-free assets. Moreover, the differences between returns on long and short strategies in markets of high and low financialization are computed and might also be interpreted as returns on strategy of taking long positions in low financialized momentum or term structure long and short portfolios and, at the same time, being short in highly financialized momentum or term structure portfolios.

All portfolios described above are reconstructed and rebalanced on a monthly basis, same as any further computations are based on monthly time series.

It is not an easy task to indicate an appropriate asset pricing model for active strategies in commodity markets. The main reasons are lack of obvious systematic risk factors and time-varying risks and exposures. Even in case of passive investment strategies, there is a broad array of benchmarks used in research and investment practice, which differ in terms of their risk-return profile ${ }^{3}$. Therefore, the performance assessment in this study bases on three distinct multifactor risk models, which follow propositions of Fuertes, Miffre, and Rallis (2010) and Fuertes, Miffre, and Fernández-Pérez (2014). 
The first model is an index model, which was employed previously by Fuertes, Miffre, and Rallis (2010):

$$
\mathrm{R}_{\mathrm{i}, \mathrm{t}}=\alpha_{i}+\mathrm{R}_{\mathrm{f}, \mathrm{t}}+\beta_{\mathrm{B}}\left(\mathrm{R}_{\mathrm{B}, \mathrm{t}}-\mathrm{R}_{\mathrm{f}, \mathrm{t}}\right)+\beta_{\mathrm{E}}\left(\mathrm{R}_{\mathrm{E}, \mathrm{t}}-\mathrm{R}_{\mathrm{f}, \mathrm{t}}\right)+\beta_{\mathrm{C}}\left(\mathrm{R}_{\mathrm{C}, \mathrm{t}}-\mathrm{R}_{\mathrm{f}, \mathrm{t}}\right)+\varepsilon_{\mathrm{i}, \mathrm{t}}
$$

where $R_{i, t}$ is the return on the tested portfolio, $R_{B, t}, R_{E, t}$, and $R_{c, t}$ are returns on bonds (JP Morgan Global Aggregate Total Return Bond Index), equities (MSCl Total Return World Index) and commodities (S\&P-GSCl Total Return Index), respectively. A proxy for a risk-free rate $R_{f, t}$ is a one-month LIBOR USD. $E_{i, t}$ is a random interference. Finally, $\alpha, \beta_{B}, \beta_{E}$ and $\beta_{C}$ are model parameters. The model reflects the point of view of an investor implementing passive investment strategies across different asset classes.

The second model is the traditional model used by Fuertes, Miffre, and Fernández-Pérez (2014), which is basically the Fama-French three factor model (Fama \& French, 1993):

$$
\mathrm{R}_{\mathrm{i}, \mathrm{t}}=\alpha_{\mathrm{i}}+\mathrm{R}_{\mathrm{f}, \mathrm{t}}+\beta_{\mathrm{rm}, \mathrm{i}} \cdot\left(\mathrm{R}_{\mathrm{m}, \mathrm{t}}-\mathrm{R}_{\mathrm{f}, \mathrm{t}}\right)+\beta_{\mathrm{SMB}} \cdot \mathrm{SMB}_{t}+\beta_{\mathrm{HML}} \cdot \mathrm{HML}_{t}+\varepsilon_{i, t}
$$

where $R_{m, t}$ is a return on a stock market portfolio, where $\beta_{r m, i}, \beta_{S M B, i}, \beta_{H M L, i}$, and $\alpha_{i}$ ere the estimated parameters of the model. $\beta_{\mathrm{rm}, \mathrm{i}}$ is analogical to the CAPM beta, but it is not equal to it. The $\beta_{\mathrm{SMB}, \mathrm{i}}, \beta_{\mathrm{HML}, \mathrm{i}}$ are exposed to $\mathrm{SMB}_{\mathrm{t}}$ (small minus big) and $\mathrm{HML}_{t}$ (high minus low) risk factors, which denote returns from zerocost arbitrage portfolios. $\mathrm{SMB}_{t}$ is the difference in returns on diversified portfolios of small and large caps at time $t$, while $H M L_{t}$ is in general difference in returns on portfolios of diversified value (high $B / V$ ) and growth (low B/V) stocks. In other words, SMB and HML are returns on zero-cost market-neutral long/short portfolios formed based on size and value characteristics ${ }^{4}$. The model reflects the point of view of traditional equity investor.

Finally, the third model is a fundamental model and it is also based on the paper by Fuertes, Miffre, and Fernández-Pérez (2014):

$$
\mathrm{R}_{\mathrm{i}, \mathrm{t}}=\alpha_{\mathrm{i}}+\mathrm{R}_{\mathrm{f}, \mathrm{t}}+\beta_{\mathrm{TS}, \mathrm{i}} \cdot \mathrm{TS}_{t}+\beta_{M O M, i} \cdot \mathrm{MOM}_{t}+\beta_{H P, i} \cdot \mathrm{HP}_{t}+\varepsilon_{i, t}
$$

In this model there are three distinct asset pricing related to term structure $\left(\mathrm{TS}_{\mathrm{t}}\right)$, commodity momentum $\left(\mathrm{MOM}_{\mathrm{t}}\right)$, and hedging pressure $\left(\mathrm{HP}_{\mathrm{t}}\right)$, and $\beta_{\mathrm{TS}, \mathrm{i}}, \beta_{M O M, \mathrm{i}}, \beta_{\mathrm{HP}, \mathrm{i}}$, are exposures to these factors. The precise construction of these factors is described in the paper by Fuertes, Miffre, \& Fernández-Pérez (2014). $\mathrm{TS}_{\mathrm{t}}, \mathrm{MOM}_{\mathrm{t}}$, and $\mathrm{HP}_{\mathrm{t}}$ are returns on long/short portfolios precisely described in Fuertes, Miffre, and FernándezPérez (2014) and Basu and Miffre (2013) ${ }^{5}$. Finally, the last model reflects the point of view an investor employing active investment strategies in commodity markets.

Basically, it is tested whether $\alpha$ is statistically different from zero. Such situation indicates that returns on a given strategy are not only a compensation for risk accompanying an efficient asset pricing. Statistical significance is tested with parametric methods, however, in the case of $\alpha$ estimation additional bootstrap simulations are employed.

\section{Research Results}

Table 2 presents summary statistics of term structure strategies. The basic strategy which relies upon the nearest and the second nearest contracts (1-2 term spread) yields an average monthly excess return of $0.92 \%$ with the standard deviation of $4.00 \%$. Its Sharpe ratio reaches 0.80 . These results are consistent with previous studies in the field that indicated the possibility of developing well-performing strategies on the basis of a term structure of a commodity market. Interestingly enough, returns on the implied-yield-based strategies are higher in the group of low financialized commodities than in the highly financialized ones. An average excess monthly return in the first case accounts for $1.43 \%$, whereas in the second one it equals only $0.41 \%$. Nevertheless, both substrategies are riskier in terms of both standard deviation and the worst month. The substrategy for the non-financialized markets seems to pose greater risks with the monthly standard deviation of $7.12 \%$ and losses exceeding $24 \%$ in the worst month. This strategy is also distinguished by the 
highest kurtosis. To sum up, the difference in returns between strategies based on 1-2 term spread implemented both in financialized and non-financialized commodity markets equals $1.02 \%$.

The above described results are generally confirmed by the performance of strategies based on alternative term spreads. The returns on 1-3 and 1-4 spread portfolios are quite similar, however, there are a few interesting differences. First, the differences of performance in non-financialized and financialized markets are positive, but relatively smaller. They equal $0.49 \%$ (1-3 spread) and $0.26 \%$ (1-4 spread). Additionally, returns in non-financialized markets are not much higher than the results for the basic strategy as in the case of 1-2 term spreads. They exceed the results for basic strategy by only 0.05 percentage point in 1-3 term spreads and the difference turns slightly negative in 1-44 term spreads. In general, it appears that market financialization level impacts strategies based on the pricing of the nearest contracts the most.

Table 2. Basic Statistics of Strategies Based on Term Structure

\begin{tabular}{|c|c|c|c|c|c|c|c|c|c|c|c|c|}
\hline & \multicolumn{4}{|c|}{ 1-2 term spread } & \multicolumn{4}{|c|}{ 1-3 term spread } & \multicolumn{4}{|c|}{ 1-4 term spread } \\
\hline & All & Non-fin & Fin & Diff & All & Non-fin & Fin & Diff & All & Non-fin & Fin & Diff \\
\hline $\begin{array}{l}\text { Average } \\
\text { excess return }\end{array}$ & 0,92 & 1,43 & 0,41 & 1,02 & 0,97 & 1,02 & 0,53 & 0,49 & 0,68 & 0,60 & 0,33 & 0,26 \\
\hline$t_{p a r}$ & $(4,14)$ & $(3,61)$ & $(1,47)$ & $(2,18)$ & $(4,46)$ & $(2,59)$ & $(1,84)$ & $(1,02)$ & $(3,07)$ & $(1,58)$ & $(1,18)$ & $(0,59)$ \\
\hline $\begin{array}{l}\text { Standard } \\
\text { deviation }\end{array}$ & 4,00 & 7,12 & 4,98 & 8,42 & 3,90 & 7,10 & 5,16 & 8,69 & 3,98 & 6,76 & 5,05 & 8,09 \\
\hline Sharpe ratio & 0,80 & 0,70 & 0,28 & 0,42 & 0,86 & 0,50 & 0,36 & 0,20 & 0,59 & 0,31 & 0,23 & 0,11 \\
\hline Skewness & 0,15 & 0,61 & $-0,37$ & 0,47 & 0,13 & 0,60 & $-0,17$ & 0,48 & 0,20 & 0,33 & $-0,19$ & 0,27 \\
\hline Kurtosis & 0,39 & 3,54 & 1,09 & 2,67 & 0,69 & 3,95 & 1,24 & 2,65 & 0,70 & 4,59 & 0,76 & 2,28 \\
\hline Worst month & $-10,04$ & $-24,63$ & $-18,58$ & $-26,19$ & $-11,06$ & $-24,63$ & $-18,58$ & $-26,19$ & $-11,73$ & $-27,56$ & $-18,58$ & $-26,19$ \\
\hline Best month & 12,95 & 38,13 & 18,96 & 40,38 & 13,60 & 38,13 & 20,21 & 40,38 & 14,14 & 38,13 & 13,73 & 40,38 \\
\hline
\end{tabular}

Description: The table presents basic statistics of strategies based on term structure. "1-2", "1-3", and "14" strategies are based on terms spreads between the first and the second, the third and the fourth contract. "All", "non-fin", and "fin" refer to the strategies implemented in all futures markets, in markets with a low level of financialization and a high level of financialization, respectively. "Dif" is the difference between low and high financialized markets. A detailed portfolios formation procedure is described in the section devoted to research methods. The numbers in brackets are test statistics.

Figure 2. Cumulative Returns on Strategies Based on Term Structure

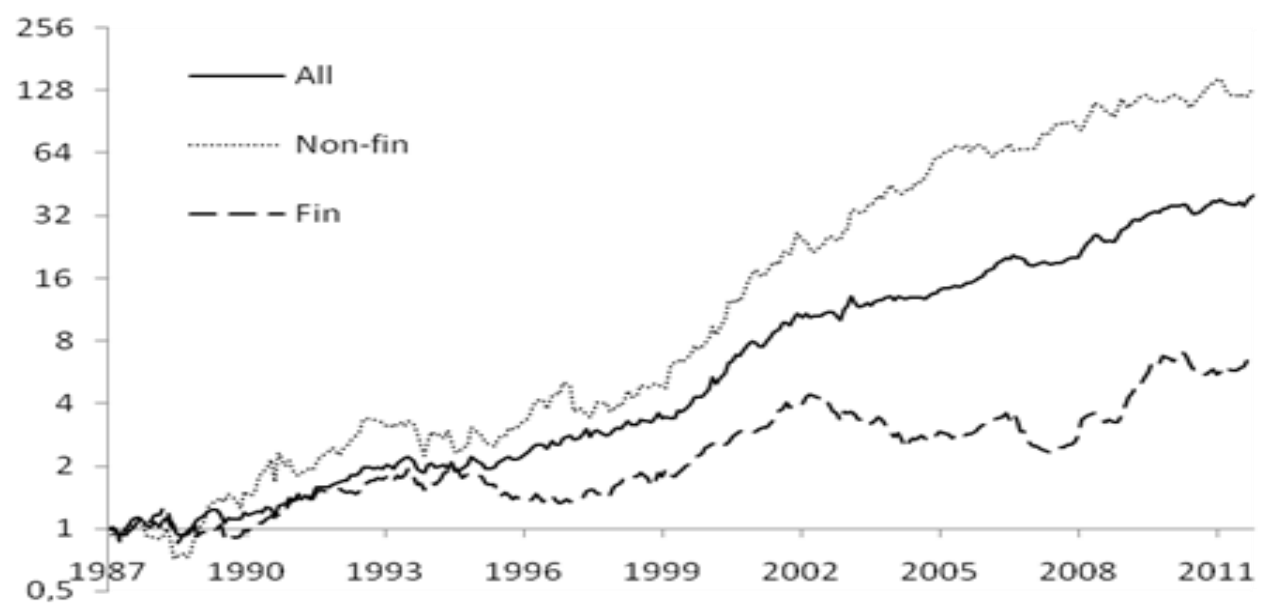

Description: The above figure presents the value of one dollar invested in the strategies based on term spread between the first and the second nearby contracts. "All", "non-fin", and "fin" refer to the strategies implemented in all futures markets, in markets with a low level of financialization and a high level of financialization, respectively. A detailed portfolios formation procedure is described in the section devoted to research methods. 
A. Zaremba

Table 3. Performance of Strategies Based on Term Structure

\begin{tabular}{|c|c|c|c|c|c|c|c|c|c|c|c|c|}
\hline & \multicolumn{4}{|c|}{ 1-2 term spread } & \multicolumn{4}{|c|}{ 1-3 term spread } & \multicolumn{4}{|c|}{ 1-4 term spread } \\
\hline & All & Non-fin & Fin & Diff & All & Non-fin & Fin & Diff & All & Non-fin & Fin & Diff \\
\hline \multicolumn{13}{|c|}{ Index model } \\
\hline GABI & 0,05 & 0,22 & 0,02 & 0,20 & 0,08 & 0,14 & 0,10 & 0,04 & 0,04 & 0,08 & $-0,02$ & 0,10 \\
\hline$t_{p a r}$ & $(0,39)$ & $(0,92)$ & $(0,09)$ & $(0,72)$ & $(0,58)$ & $(0,58)$ & $(0,56)$ & $(0,13)$ & $(0,30)$ & $(0,35)$ & $(-0,09)$ & $(0,35)$ \\
\hline $\mathrm{MSCl}$ & $-0,05$ & $-0,10$ & $-0,01$ & $-0,09$ & $-0,05$ & $-0,14$ & 0,01 & $-0,15$ & $-0,01$ & $-0,15$ & 0,07 & $-0,23$ \\
\hline$t_{\text {par }}$ & $(-0,87)$ & $(-1,11)$ & $(-0,17)$ & $(-0,82)$ & $(-1,00)$ & $(-1,53)$ & $(0,18)$ & $(-1,35)$ & $(-0,24)$ & $(-1,76)$ & $(1,11)$ & $(-2,17)$ \\
\hline $\mathrm{GSCl}$ & 0,14 & 0,36 & $-0,01$ & 0,38 & 0,14 & 0,30 & 0,00 & 0,30 & 0,16 & 0,30 & 0,00 & 0,30 \\
\hline$t_{\text {par }}$ & $(3,57)$ & $(5,49)$ & $(-0,27)$ & $(4,76)$ & $(3,66)$ & $(4,47)$ & $(-0,10)$ & $(3,68)$ & $(4,30)$ & $(4,68)$ & $(-0,04)$ & $(3,91)$ \\
\hline$\alpha$ & 0,88 & 1,29 & 0,41 & 0,88 & 0,92 & 0,94 & 0,51 & 0,43 & 0,62 & 0,53 & 0,31 & 0,22 \\
\hline$t_{\text {par }}$ & $(3,97)$ & $(3,38)$ & $(1,47)$ & $(1,92)$ & $(4,28)$ & $(2,42)$ & $(1,74)$ & $(0,90)$ & $(2,85)$ & $(1,43)$ & $(1,09)$ & $(0,49)$ \\
\hline$t_{\text {non-par }}$ & $(4,28)$ & $(3,83)$ & $(1,47)$ & $(2,32)$ & $(4,39)$ & $(2,61)$ & $(1,77)$ & $(0,99)$ & $(3,21)$ & $(1,59)$ & $(1,16)$ & $(0,53)$ \\
\hline \multicolumn{13}{|c|}{ Traditional model } \\
\hline Mkt-RF & $-0,02$ & $-0,01$ & 0,01 & $-0,02$ & $-0,03$ & $-0,07$ & 0,04 & $-0,11$ & 0,00 & $-0,11$ & 0,11 & $-0,22$ \\
\hline$t_{p a r}$ & $(-0,32)$ & $(-0,11)$ & $(0,17)$ & $(-0,19)$ & $(-0,65)$ & $(-0,77)$ & $(0,62)$ & $(-1,00)$ & $(0,01)$ & $(-1,24)$ & $(1,64)$ & $(-2,06)$ \\
\hline SMB & 0,22 & 0,16 & 0,09 & 0,07 & 0,20 & 0,15 & 0,09 & 0,07 & 0,27 & 0,29 & 0,14 & 0,15 \\
\hline$t_{\text {par }}$ & $(3,00)$ & $(1,20)$ & $(0,96)$ & $(0,45)$ & $(2,78)$ & $(1,17)$ & $(0,90)$ & $(0,43)$ & $(3,78)$ & $(2,29)$ & $(1,47)$ & $(1,00)$ \\
\hline HML & 0,01 & $-0,08$ & 0,10 & $-0,18$ & $-0,01$ & $-0,11$ & 0,08 & $-0,19$ & 0,05 & $-0,03$ & 0,13 & $-0,16$ \\
\hline$t_{\text {par }}$ & $(0,17)$ & $(-0,54)$ & $(1,03)$ & $(-1,07)$ & $(-0,13)$ & $(-0,77)$ & $(0,83)$ & $(-1,12)$ & $(0,69)$ & $(-0,21)$ & $(1,32)$ & $(-1,00)$ \\
\hline$\alpha$ & 0,90 & 1,43 & 0,36 & 1,07 & 0,96 & 1,07 & 0,47 & 0,60 & 0,63 & 0,63 & 0,21 & 0,41 \\
\hline$t_{p a r}$ & $(4,00)$ & $(3,55)$ & $(1,29)$ & $(2,24)$ & $(4,39)$ & $(2,66)$ & $(1,61)$ & $(1,22)$ & $(2,84)$ & $(1,64)$ & $(0,76)$ & $(0,90)$ \\
\hline$t_{\text {non-par }}$ & $(4,27)$ & $(4,14)$ & $(1,29)$ & $(2,64)$ & $(4,48)$ & $(2,88)$ & $(1,63)$ & $(1,36)$ & $(3,12)$ & $(1,78)$ & $(0,80)$ & $(0,97)$ \\
\hline \multicolumn{13}{|c|}{ Fundamental model } \\
\hline TS & 0,49 & 0,57 & 0,19 & 0,38 & 0,36 & 0,48 & 0,02 & 0,45 & 0,42 & 0,46 & 0,15 & 0,31 \\
\hline$t_{p a r}$ & $(6,36)$ & $(4,02)$ & $(1,85)$ & $(2,24)$ & $(4,67)$ & $(3,34)$ & $(0,23)$ & $(2,57)$ & $(5,53)$ & $(3,42)$ & $(1,41)$ & $(1,88)$ \\
\hline MOM & 0,12 & 0,29 & 0,03 & 0,26 & 0,22 & 0,37 & 0,08 & 0,29 & 0,27 & 0,40 & 0,10 & 0,29 \\
\hline$t_{p a r}$ & $(1,76)$ & $(2,36)$ & $(0,31)$ & $(1,78)$ & $(3,28)$ & $(2,99)$ & $(0,84)$ & $(1,91)$ & $(4,18)$ & $(3,40)$ & $(1,15)$ & $(2,04)$ \\
\hline HP & 0,12 & $-0,52$ & 0,26 & $-0,77$ & 0,08 & $-0,47$ & 0,26 & $-0,73$ & 0,03 & $-0,50$ & 0,14 & $-0,64$ \\
\hline$t_{p a r}$ & $(1,53)$ & $(-3,66)$ & $(2,53)$ & $(-4,59)$ & $(1,03)$ & $(-3,32)$ & $(2,43)$ & $(-4,17)$ & $(0,40)$ & $(-3,74)$ & $(1,36)$ & $(-3,92)$ \\
\hline$\alpha$ & 0,66 & 1,30 & 0,23 & 1,06 & 0,72 & 0,87 & 0,39 & 0,48 & 0,40 & 0,44 & 0,18 & 0,26 \\
\hline$t_{p a r}$ & $(3,17)$ & $(3,39)$ & $(0,84)$ & $(2,32)$ & $(3,49)$ & $(2,25)$ & $(1,34)$ & $(1,01)$ & $(1,96)$ & $(1,22)$ & $(0,63)$ & $(0,59)$ \\
\hline$t_{\text {non-par }}$ & $(3,44)$ & $(3,84)$ & $(0,84)$ & $(2,73)$ & $(3,57)$ & $(2,47)$ & $(1,37)$ & $(1,11)$ & $(2,24)$ & $(1,37)$ & $(0,67)$ & $(0,64)$ \\
\hline
\end{tabular}

Description. The table presents the risk-adjusted performance of strategies based on term structure. "GABI" is JP Morgan Global Aggregate Total Return Bond Index, "MSCl" is MSCl Total Return World Index, and GSCl is S\&P-GSCl Total Return Index. "Mkt-Rf,", "SMB", and "HML" are factors from Fama-French (1993) threefactor model. "TS", MOM", and "HP" are respectively term-structure, commodity momentum and hedging pressure factors from a fundamental model by Fuertes, Miffre, \& Fernandez-Perez (2014). The first rows are estimations of the coefficient of the corresponded variables, while the numbers in brackets are test statistics. "1-2", "1-3", and "1-4" strategies are based terms spreads between the first and the second, the third and the fourth contract. "All", "non-fin", and "fin" refer to the strategies implemented in all futures markets, in markets with a low level of financialization and a high level of financialization, respectively. "Dif" is the difference between low and high financialized markets. A detailed portfolios formation procedure is described in the section devoted to research methods. 
Figure 2 is a graphical presentation of cumulative returns on1-2 term structure strategies in markets with various degree of financialization. The scale of difference seems to be fairly impressive. Each dollar invested in non-financialized markets in the beginning of 1987 returns134 dollars at the end of 2013. On the contrary, cumulative returnson investment in financialized markets equal to only $647 \%$. In other words, it clearly appears that returns on term structure strategies are gained in markets with lowlevel of financialization.

Table 3 presents the results of formal statistical analysis of term structure strategies. First of all, concentrating on the index model, it seems that the performance of long and short portfolios is not well explained by pricing factors related to bonds or equities. However, low exposure to commodity markets is statistically significant across all portfolios, except for investments in financialized markets. Focusing on strategies based on 1-2 term spreads, they are distinguished by a positive and very positive intercept which equals to $0.88 \%$ monthly. The alpha rises to $1.29 \%$ monthly in non-financialized market, however, it decreases to only $0.41 \%$ monthly in financialized markets and is not statistically significant. The difference between the performance of both strategies (or, in other words, the performance of long term spread strategy in low financialized markets short term strategy in markets of high financialization) is positive and statistically significant.

The traditional model is also not able to explain well the returns on term structure strategies. The asset pricing factors are not statistically significant, with the exception of SMB. This observation is not fully consistent with the paper by Brooks et al. (2014), who do not document significant correlation of the term structure strategy with SMB factor, however the inconsistencies may stem from differences in strategy design and portfolio construction. Nonetheless, the basic conclusions from the index model withstand. The strategy is characterized by statistically significant intercept of $0.90 \%$ (1-2 spread). The strategy performs better in non-financialized than in financialized markets, and the difference is statistically significant and equal $1.07 \%$ for 1-2 spread. For the other variations of the strategy the intercepts of differences vary from $0.41 \%$ to $0.60 \%$ and are not significant.

Finally, the fundamental model suits best for the term-stucture based strategies, particularly due to TS factor, which explains well the returns. Furthermore, the differences in returns are also negatively influence by the HP factor. Nevertheless, even after application of the fundamental model, the investigated strategy performs better in non-financialized markets than in financialized. The alpha of the statistically significant difference is equal $1.06 \%$ for $1-2$ spread. For the other spreads the intercepts are equal $0.26-0.48 \%$ and lack statistical significance.

Alternative term spread strategies generally confirm the above described results, but lack statistical significance. Returns on long and short portfolios based on term spreads are higher in non-financialized markets than in financialized markets, however, the difference is no longer statistically significant.

Summing up, results of term structure strategies analysis confirm initial assumptions. Performance of portfolios based on term spreads depends on the level of financialization. It seems to be the highest in non-financialized markets and rather disappointing in financialized markets.

Table 4 presents summary statistics of momentum strategies. Monthly average excess returns are lower than returns on implied-yield-based strategies, but they generally follow similar patterns. Strategies yield positive returns which, in fact, are higher than returns in longer formation periods. These observations are basically consistent with the results of previous studies in the field (Miffre \& Rallis, 2007). An average monthly excess return on one-month momentum is $0.39 \%$, while on twelve-month momentum it accounts for $0.74 \%$. In all the three types of momentum analyzed returns are higher in non-financialized markets than in financialized markets, although higher returns come at higher risk. For instance, an average excess return on one-month momentum equals $0.65 \%$ in non-financialized commodity markets and $0.15 \%$ in financialized ones. However, a standard deviation is higher for non-financialized markets ( $8.03 \%$ vs $5.27 \%$ in financialized markets), while Sharpe ratio is generally the highest with low presence of non-commercial market participants. 
A. Zaremba

Table 4. Basic Statistics of Strategies Based on Momentum

\begin{tabular}{|c|c|c|c|c|c|c|c|c|c|c|c|c|}
\hline & \multicolumn{4}{|c|}{ 1-month momentum } & \multicolumn{4}{|c|}{ 3-month momentum } & \multicolumn{4}{|c|}{ 12-month momentum } \\
\hline & All & Non-fin & Fin & Diff & All & Non-fin & Fin & Diff & All & Non-fin & Fin & Diff \\
\hline $\begin{array}{l}\text { Average } \\
\text { excess return }\end{array}$ & 0,39 & 0,65 & 0,15 & 0,50 & 0,65 & 0,76 & 0,36 & 0,40 & 0,74 & 0,93 & 0,66 & 0,26 \\
\hline$t_{p a r}$ & $(1,38)$ & $(1,45)$ & $(0,51)$ & $(0,99)$ & $(2,60)$ & $(1,84)$ & $(1,24)$ & $(0,79)$ & $(2,79)$ & $(2,09)$ & $(2,28)$ & $(0,52)$ \\
\hline $\begin{array}{l}\text { Standard } \\
\text { deviation }\end{array}$ & 5,09 & 8,03 & 5,27 & 9,01 & 4,50 & 7,46 & 5,29 & 9,10 & 4,79 & 7,93 & 5,21 & 9,15 \\
\hline Sharpe ratio & 0,80 & 0,70 & 0,28 & 0,42 & 0,86 & 0,50 & 0,36 & 0,20 & 0,59 & 0,31 & 0,23 & 0,11 \\
\hline Skewness & 0,40 & 1,33 & $-0,07$ & 0,58 & 0,30 & 0,92 & 0,04 & 0,27 & 0,21 & 0,72 & 0,25 & 0,19 \\
\hline Kurtosis & 2,95 & 9,83 & 0,71 & 4,32 & 1,65 & 6,19 & 0,82 & 3,13 & 1,65 & 5,07 & 1,25 & 3,86 \\
\hline Worst month & $-20,38$ & $-25,09$ & $-16,26$ & $-27,95$ & $-17,55$ & $-27,62$ & $-16,51$ & $-38,58$ & $-18,55$ & $-28,23$ & $-14,91$ & $-45,03$ \\
\hline Best month & 25,04 & 53,73 & 18,33 & 49,31 & 20,10 & 48,85 & 16,80 & 47,91 & 20,10 & 48,85 & 17,47 & 47,91 \\
\hline
\end{tabular}

Description: The table presents basic statistics of strategies based on momentum. 1, 3 and 12 months refer to the sorting period in momentum strategies. "All", "non-fin", and "fin" refer to the strategies implemented in all futures markets, in markets with a low level of financialization and a high level of financialization, respectively. "Dif" is the difference between low and high financialized markets. A detailed portfolios formation procedure is described in the section devoted to research methods. The numbers in brackets are test statistics.

Figure 3. Cumulative Returns on Strategies Based on Term Structure

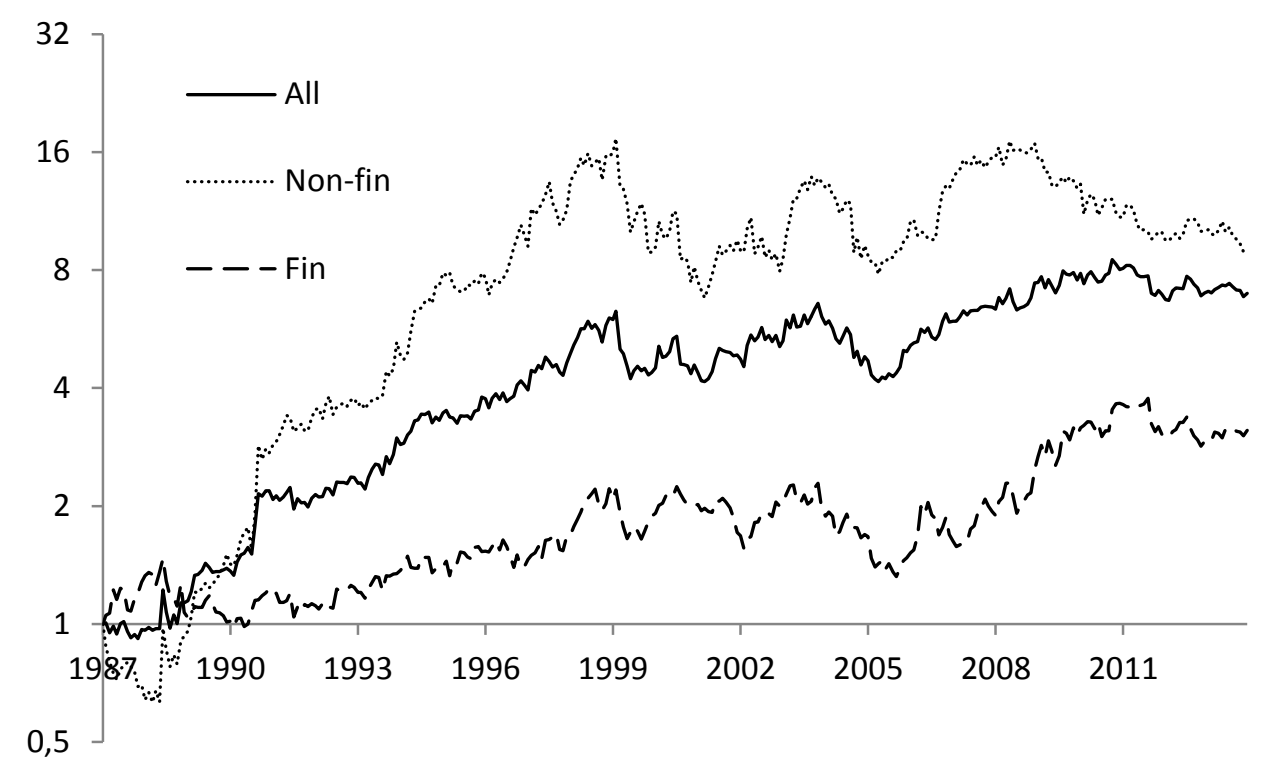

Description: The above figure presents the value of one dollar invested in the strategies based on term spread between the first and the second nearby contracts. "All", "non-fin", and "fin" refer to the strategies implemented in all futures markets, in markets with a low level of financialization and a high level of financialization, respectively. A detailed portfolios formation procedure is described in the section devoted to research methods.

Figure 3 presents cumulative returns on momentum strategy. The prevalence of performance in low financialized markets is visible, but not so evident in the case of term structurebased strategies. Each one dollar invested in non-financialized markets in the beginning of 1987 yields9 dollars at the end of 2013. Although this return is not so high, it still remains impressive when compared to the performance of financialized markets where this strategy yielded barely any return. A cumulative profit onone dollar equals modest 2 dollars and 12 cents. 
Strategies Based on Momentum and Term Structure in Financialized Commodity Markets

Table 5. Performance of Strategies Based on Momentum

\begin{tabular}{|c|c|c|c|c|c|c|c|c|c|c|c|c|}
\hline & \multicolumn{4}{|c|}{ 1-month momentum } & \multicolumn{4}{|c|}{ 3-months momentum } & \multirow[b]{2}{*}{ All } & \multicolumn{3}{|c|}{ 12-months momentum } \\
\hline & All & Non-fin & Fin & Diff & All & Non-fin & Fin & Diff & & Non-fin & Fin & Diff \\
\hline \multicolumn{13}{|c|}{ Index model } \\
\hline GABI & $-0,04$ & $-0,03$ & 0,00 & $-0,02$ & $-0,01$ & 0,22 & 0,08 & 0,15 & 0,06 & 0,09 & 0,14 & $-0,06$ \\
\hline$t_{\text {par }}$ & $(-0,20)$ & $(-0,09)$ & $(-0,01)$ & $(-0,07)$ & $(-0,06)$ & $(0,89)$ & $(0,42)$ & $(0,48)$ & $(0,34)$ & $(0,31)$ & $(0,78)$ & $(-0,18$ \\
\hline $\mathrm{MSCl}$ & $-0,05$ & $-0,06$ & $-0,03$ & $-0,04$ & $-0,07$ & $-0,20$ & $-0,01$ & $-0,19$ & $-0,07$ & $-0,25$ & 0,04 & $-0,29$ \\
\hline$t_{\text {par }}$ & $(-0,67)$ & $(-0,59)$ & $(-0,36)$ & $(-0,32)$ & $(-1,12)$ & $(-2,07)$ & $(-0,14)$ & $(-1,61)$ & $(-1,19)$ & $(-2,41)$ & $(0,64)$ & $(-2,46$ \\
\hline $\mathrm{GSCl}$ & $-0,02$ & 0,01 & $-0,11$ & 0,11 & 0,13 & 0,32 & $-0,07$ & 0,40 & 0,11 & 0,22 & $-0,01$ & 0,23 \\
\hline$t_{\text {par }}$ & $(-0,47)$ & $(0,07)$ & $(-2,14)$ & $(1,30)$ & $(2,93)$ & $(4,61)$ & $(-1,45)$ & $(4,64)$ & $(2,32)$ & $(2,84)$ & $(-0,27)$ & $(2,61)$ \\
\hline$\alpha$ & 0,42 & 0,67 & 0,20 & 0,47 & 0,63 & 0,67 & 0,38 & 0,30 & 0,72 & 0,92 & 0,62 & 0,3 \\
\hline$t_{p a r}$ & $(1,47)$ & $(1,49)$ & $(0,67)$ & $(0,94)$ & $(2,52)$ & $(1,66)$ & $(1,27)$ & $(0,60)$ & $(2,69)$ & $(2,09)$ & $(2,12)$ & $(0,59$ \\
\hline$t_{\text {non-par }}$ & $(1,34)$ & $(1,50)$ & $(0,55)$ & $(1,01)$ & $(2,50)$ & $(1,78)$ & $(1,30)$ & $(0,76)$ & $(2,68)$ & $(2,08)$ & $(2,22)$ & $(0,52$ \\
\hline \multicolumn{13}{|c|}{ Traditional model } \\
\hline Mkt-Rf & $-0,04$ & 0,02 & $-0,08$ & 0,10 & $-0,03$ & $-0,11$ & 0,03 & $-0,14$ & $-0,01$ & $-0,13$ & 0,11 & $-0,2$ \\
\hline$t_{p a r}$ & $(-0,63)$ & $(0,18)$ & $(-1,21)$ & $(0,87)$ & $(-0,53)$ & $(-1,08)$ & $(0,43)$ & $(-1,14)$ & $(-0,18)$ & $(-1,24)$ & $(1,63)$ & $(-2,01)$ \\
\hline SMB & 0,15 & 0,12 & 0,01 & 0,11 & 0,05 & 0,07 & $-0,06$ & 0,12 & 0,11 & 0,24 & 0,02 & 0,2 \\
\hline$t_{\text {par }}$ & $(1,57)$ & $(0,80)$ & $(0,08)$ & $(0,66)$ & $(0,61)$ & $(0,49)$ & $(-0,57)$ & $(0,73)$ & $(1,27)$ & $(1,62)$ & $(0,17)$ & $(1,31)$ \\
\hline HML & $-0,07$ & $-0,10$ & $-0,08$ & $-0,02$ & $-0,05$ & $-0,23$ & 0,02 & $-0,25$ & $-0,10$ & $-0,20$ & 0,00 & $-0,20$ \\
\hline$t_{p a r}$ & $(-0,69)$ & $(-0,64)$ & $(-0,76)$ & $(-0,12)$ & $(-0,54)$ & $(-1,54)$ & $(0,20)$ & $(-1,38)$ & $(-1,08)$ & $(-1,27)$ & $(0,02)$ & $(-1,11$ \\
\hline$\alpha$ & 0,41 & 0,64 & 0,22 & 0,42 & 0,67 & 0,87 & 0,35 & 0,52 & 0,76 & 1,01 & 0,59 & 0,4 \\
\hline$t_{p a r}$ & $(1,43)$ & $(1,41)$ & $(0,73)$ & $(0,83)$ & $(2,64)$ & $(2,07)$ & $(1,16)$ & $(1,02)$ & $(2,80)$ & $(2,27)$ & $(2,01)$ & $(0,82$ \\
\hline$t_{\text {non-par }}$ & $(1,27)$ & $(1,42)$ & $(0,60)$ & $(0,90)$ & $(2,62)$ & $(2,25)$ & $(1,18)$ & $(1,24)$ & $(2,79)$ & $(2,26)$ & $(2,12)$ & $(0,74$ \\
\hline \multicolumn{13}{|c|}{ Fundamental model } \\
\hline TS & $-0,25$ & $-0,60$ & $-0,01$ & $-0,58$ & 0,04 & $-0,04$ & $-0,06$ & 0,02 & 0,13 & 0,12 & $-0,05$ & 0,17 \\
\hline$t_{p a r}$ & $(-2,43)$ & $(-3,68)$ & $(-0,11)$ & $(-3,14)$ & $(0,52)$ & $(-0,31)$ & $(-0,59)$ & $(0,10)$ & $(1,62)$ & $(0,80)$ & $(-0,49)$ & $(0,91)$ \\
\hline MOM & 0,41 & 0,63 & 0,15 & 0,49 & 0,59 & 0,93 & 0,31 & 0,62 & 0,82 & 1,18 & 0,44 & 0,7 \\
\hline$t_{\text {par }}$ & $(4,67)$ & $(4,53)$ & $(1,54)$ & $(3,03)$ & $(7,97)$ & $(7,44)$ & $(3,31)$ & $(3,90)$ & $(11,74)$ & $(9,33)$ & $(4,99)$ & $(4,67)$ \\
\hline HP & 0,14 & 0,13 & 0,21 & $-0,08$ & $-0,07$ & $-0,42$ & 0,30 & $-0,72$ & $-0,03$ & $-0,48$ & 0,33 & $-0,81$ \\
\hline$t_{p a r}$ & $(1,34)$ & $(0,81)$ & $(1,96)$ & $(-0,46)$ & $(-0,79)$ & $(-2,91)$ & $(2,81)$ & $(-3,90)$ & $(-0,40)$ & $(-3,33)$ & $(3,26)$ & $(-4,47$ \\
\hline$\alpha$ & 0,22 & 0,49 & 0,00 & 0,48 & 0,38 & 0,48 & 0,12 & 0,36 & 0,31 & 0,50 & 0,34 & 0,15 \\
\hline$t_{p a r}$ & $(0,80)$ & $(1,11)$ & $(0,01)$ & $(0,96)$ & $(1,64)$ & $(1,24)$ & $(0,43)$ & $(0,72)$ & $(1,44)$ & $(1,26)$ & $(1,24)$ & $(0,31)$ \\
\hline$t_{\text {non-par }}$ & $(0,74)$ & $(1,12)$ & $(0,01)$ & $(1,03)$ & $(1,63)$ & $(1,35)$ & $(0,44)$ & $(0,86)$ & $(1,43)$ & $(1,25)$ & $(1,31)$ & $(0,27$ \\
\hline
\end{tabular}

Description. The table presents the risk-adjusted performance of strategies based on momentum. 1, 3 and 12 months refer to the sorting period in momentum strategies. "GABI" is JP Morgan Global Aggregate Total Return Bond Index, "MSCl" is MSCl Total Return World Index, and GSCl is S\&P-GSCl Total Return Index. "Mkt$R f$,", "SMB", and "HML" are factors from Fama-French (1993) three-factor model. "TS", MOM", and "HP" are respectively term-structure, commodity momentum and hedging pressure factors from a fundamental model by Fuertes, Miffre, \& Fernandez-Perez (2014). The first rows are estimations of the coefficient of the corresponded variables, while the numbers in brackets are test statistics. "All", "non-fin", and "fin" refer to the strategies implemented in all futures markets, in markets with a low level of financialization and a high level of financialization, respectively. "Dif" is the difference between low and high financialized markets. A detailed portfolios formation procedure is described in the section devoted to research methods.

Formal statistical tests of single-sorted and double-sorted portfolios yield rather mixed results (see Table 5). Focusing on the index model first, strategies show generally no significant exposure to equity and bond risk factors, however, returns on long-term momentum ( 3 and 12 months) are related to commodity markets. Additionally, abnormal returns on commodity momentum investments are positive across all 
variations of the basic strategy, however, they are statistically significant only in the case of broad-market portfolios developed on the basis of sorts on 3-month and 12-month scenarios. In each version of momentum alphas in non-financialized markets are higher than those in financialized ones. Intercepts of differences are positive in all cases, ranging from $0.30 \%$ to $0.47 \%$, however, they lack statistical significance.

The outcomes of the traditional model are basically similar, although none of the pricing factors do a good job at explaining the returns. All of them are not statistically significant. The performance of the momentum strategy in markets of low financialization is superior to markets with high financialization. The alphas of the difference range from $0.42 \%$ to $0.52 \%$ for 1 -month momentum, but it is not statistically significant.

The fundamental model, analogously to the case of the term-structure strategy, seems to perform the best, mainly due to statistically significant momentum factor. Moreover, also the term-structure factor is statistically significant, but negative. The intercepts from the fundamental model also support the hypothesis that the momentum strategy performs better in non-financialized markets, but are not conclusive The alphas of differences in returns are equal $0.15-0.48 \%$ for various variation of the momentum strategy.

Summing up the discussion on performance of commodity market strategies, calculated results generally confirm the initial assumption, but are far from being conclusive. Performance of momentum strategies is higher in low financialized markets than in markets of high financialization. This observation remains true across all types of momentum investments investigated in this paper. However, differences are smaller than in the case of term structure strategies. "Alphas", though positive, are not statistically different from zero.

\section{Concluding Remarks}

The aim of this paper is to investigate a potential negative impact of financialization on tactical asset allocation opportunities in commodity markets. Performed computations generally support the initial assumption. Term structure strategies perform significantly better in non-financialized markets than in financialized ones. The level of profitability based on momentum is lower in markets of high financialization, what comes in line with the assumptions of this study. Nonetheless, results are far from being conclusive as they lack statistical significance, despite the fact that this observation supports the hypothesis of negative impact of market financialization on the profitability of momentum strategies.

The above described results are important in terms of asset allocation in commodity markets. Basically, they imply that investors who implement momentum or term structure based strategies should also consider the composition of market participants. The more crowded is a market with financial investors, the lower are profits from pursuing tactical opportunities. Investors pursuing strategies based on momentum and term-structure could benefit from focusing on not highly financialized markets and resigning from investments in financialized markets. These observations also explain cross-sectional variations in futures returns and, thus, could be implemented in a formal asset pricing model.

A serious limitation in this study is a relatively small sample size which might pose a risk of small sample bias. Alas, it appears that any significant expansion of a sample might be difficult due to the nature of commodity markets. Basically, the number of commodities examined in the paper is typical for similar studies of commodity investments.

Any further studies should concentrate on at least three issues. First of all, it would be interesting to verify the usefulness of market financialization as an asset allocation to factors across various asset classes. Secondly, observations of relations occurring between momentum and term structure-based strategies should be implemented in a formal asset pricing model. Finally, other potential consequences of market financialization for commodity investors should be explored. 


\section{End Notes}

${ }^{1}$ Probably the only exception so far is a working paper by Neuhierl and Thompson (2014), which basically investigated performance of momentum strategies in pre-2005 and post-2005. They find, that the returns were higher in the post2005 period, which coincided with the increased investors' activity in commodity markets.

2 A notable exception is a measure called "speculative T-index" devised by Working [1960], which was employed for example by Sanders et al. [2008]. However, the intention of this measure is rather to indicate an excessive speculation, so in it does not incorporate information on both sides of the speculative markets (long and short positions) simultaneously. As a result of that, to some extend it reminds measures of hedging pressure than of the financialization.

${ }^{3}$ Some reviews of benchmarks for commodity investments are available in papers by Fuss et al. (2008) and Schneeweis et al. (2008).

4 The data on the asset pricing factors comes from Kenneth R. French's website: http://mba.tuck.dartmouth.edu/pages/faculty/ken.french/.

${ }^{5}$ Author would like to thank Adrian Fernández-Pérez for providing time-series with TS, MOM and HP asset pricing factors.

\section{References}

Abanomey, W.S. \& Mathur, I. (2001). Intercontinental Portfolios with Commodity Futures and Currency Forward Contracts, Journal of Investing, 10, 61-68.

Adams, Z., Füss., R. \& Kaiser, G.K. (2008). Macroeconomic Determinants of Commodity Futures Returns, in F.J. Fabozzi, R. Füss \& D.G. Kaiser (eds.)The Handbook of Commodity Investing (pp. 87-112), New York: Wiley.

Ankrim, E.M. \& Hensel, C.R. (1993). Commodities in Asset Allocation: A Real-Asset Alternative to Real Estate. Financial Analyst Journal, 49, 20-29.

Anson, M.J.P. (1999). Spot Returns, Roll Yield and Diversification with Commodity Futures. Journal of Alternative Investments, 4, 1-17.

Armstead, K.J. \& Venkatraman, R. (2007). Commodity Returns - Implications for Active Management. H. Till \& J. Eagleeye (eds.) Intelligent Commodity Investing: New Strategies and Practical Insights for Informed Decision Makings (pp. 293-312),London: Risk Books.

Asness, C.S., Liew, J.M. \& Stevens, R.L. (1997). Parallels between the cross-sectional predictability of stock and country returns. Journal of Portfolio Management, 23, 79-87.

Asness, C.S., Moskowitz, T.J. \& Pedersen, L.H. (2013). Value and Momentum Everywhere. Journal of Finance, 68, 929986.

Barberis, N., Schleifer, A. \& Vishny, R. (1998). A Model of Investor Sentiment. Journal of Financial Economics, 49, 307343.

Basu, D. \& Miffre, J. (2013). Capturing the Risk Premium of Commodity Futures: The Role of Hedging Pressure. Journal of Banking and Finance, 37, 2652-2664.

Becker, K.G. \& Finnerty, J.E. (1994). Indexed Commodity Futures and the Risk of Institutional Portfolios. OFOR working paper, nr 94-02, January.

Bhojraj, \& Swaminathan, B. (2006). Macromomentum: Returns predictability in international equity indices. Journal of Business, 79, 429-451.

Bikhchandani, S., Hirshleifer, D. \& Welch, I. (1992). A Theory of Fads, Fashion, Custom, and Cultural Change as Informational Cascades. Journal of Political Economy, 100, $992-1026$.

Brooks, C., Fernández-Pérez, A., Miffre, J., \& Nneji, O. (2014). Commodity Risk Factors and the Cross-Section of Equity Returns. working paper, available at SSRN: http://ssrn.com/abstract=2490347 or http://dx.doi.org/10.2139/ssrn.2490347 (retrieved 13 November 2014).

Brunetti, C. \& Reiffen, D. (2011). Commodity Index Trading and Hedging Costs. Division of Research \& Statistics and Monetary Affairs, Federal Reserve Board, Washington, available at SSRN: http://dx.doi.org/10.2139/ssrn.1727723, (retrieved 19 November 2014).

Cheng, I.H. \& Xiong, W. (2013). The Financialization of Commodity Markets. working paper, available at SSRN: http://dx.doi.org/10.2139/ssrn.2350243, (retrieved 19 November 2014).

Chui, A., Titman, \& Wei, K.C.J. (2010). Individualism and momentum around the world. Journal of Finance, 65, 361-392. 
De Long, J.B., Shleifer A., Summers, L.H. \& Waldmann, R.J. (1990). Positive feedback investment strategies and destabilizing rational speculation. Journal of Finance, 45, $379-395$.

De Roon F., Nijman T.E. \& Veld C. (2000). Hedging Pressure Effects in Futures Markets. Journal of Finance, 55 , 1437 1456.

Deaton, A. \& Laroque, G. (1992). On the Behavior of Commodity Prices. Review of Economic Studies, 59, 1-23.

Domanski, D. \& Heath, A. (2007). Financial Investors and Commodity Markets.BIS Quarterly Review, March 2007, available at SSRN: http://ssrn.com/abstract=1600058, (retrieved 19 November 2014).

Einloth, J.T. (2009). Speculation and Recent Volatility in the Price of Oil. FDIC working paper, available at SSRN: http://dx.doi.org/10.2139/ssrn.1488792, (retrieved 19 November 2014).

Erb, C.B. \& Harvey C.R. (2006). The Strategic and Tactical Value of Commodity Futures. Financial Analyst Journal, 62, 6997.

Fama, E.F. \& French, K.R. (1993). Common Risk Factors in the Returns on Stocks and Bonds. Journal of Financial Economics, 33(1), 3-56.

Fama, E.F., French, K.R. (2012). Size, value, and momentum in international stock returns. Journal of Financial Economics, 105, 457-472.

Froot, K.A., Scharfstein, D.S. \& Stein, J.C. (1992). Herd on the Street: Informational Inefficiencies in a Market with ShortTerm Speculation. Journal of Finance, 47, $1461-1484$.

Fuertes, A.M., Miffre, J. \& Fernández-Pérez, A. (2014). Commodity Strategies Based on Momentum, Term Structure and Idiosyncratic Volatility. Journal of Futures Markets, forthcoming.

Fuertes, A.M., Miffre, J. \& Rallis, G. (2010). Tactical Allocation in Commodity Futures Markets: Combining Momentum and Term Structure Signals. Journal of Banking and Finance, 34, 2530-2548.

Fuss, R., Hoppe, C., \& Kaiser, D.G. (2008). Review of Commodity Futures Performance Benchmarks. F.J. Fabozzi, R. Fuss, \& D.G. Kaiser (eds.)The Handbook of Commodity Investing (pp. 169-202). Hoboken: Wiley.

Garleanu, N. \& Pedersen, L.H. (2007). Liquidity and Risk Management. American Economic Review, 97, 193 - 197.

Georgiev, G. (2001). Benefits of Commodity Investment. Journal of Alternative Investments, 10, 40-48.

Gilbert, C.L. (2010a). Speculative Influences on Commodity Futures Prices 2006-2008.UNCTAD working paper nr 197, available at: http://unctad.org/en/Docs/osgdp20101_en.pdf, (retrieved 19 November 2014).

Gilbert, C.L. (2010b). How to Understand High Food Prices. Journal of Agricultural Economics, 61, 398-425.

Gorton, G.B. \& Rouwenhorst, K.G. (2006). Facts and Fantasies about Commodity Futures. Financial Analyst Journal, 62, 47-68.

Gorton, G.B., Hayashi, F. \& Rouwenhorst, K.G. (2013). The Fundamentals of Commodity Futures Returns. Review of Finance, 17, 35-105.

Griffin, J., Ji \& Spencer M. (2003). Momentum investing and business cycle risk: Evidence from pole to pole. Journal of Finance, 58, 1515-1547.

Hirshleifer, D. (1990). Hedging pressure and future price movements in a general equilibrium model.Econometrica,58, 441-28.

Irwin, S.H. \& Sanders, D.R. (2012). Financialization and Structural Change in Commodity Futures Markets. Journal of Agricultural and Applied Economics, 44, 371-396.

Jegadeesh, N. \& Titman (1993). Returns to buying winners and selling losers: Implications for stock market efficiency. Journal of Finance, 48, 65-91.

Jensen, G., Johnson, R. \& Mercer, J (2000). Efficient Use of Commodity Futures in Diversified Portfolios. Journal of Futures Markets, 20, 489-506.

Kahneman, D., Tversky, A. (1974). Judgment under Uncertainty: Heuristics and Biases.Science, 185, 1124 - 1131.

Kaplan, P.D. \& Lummer, S.L. (1998). Update: GSCl Collateralized Futures as a Hedging and Diversification Tool for Institutional Portfolios. Journal of Investing, 7, 11-17.

Keynes, J.M (1930).A Treatise on Money. London: Macmillan.

Kho, B.C. (1996). Time-varying risk premia, volatility, and technical trading rule profits: Evidence from foreign currency futures markets. Journal of Financial Economics, 41, 249-290.

LeBaron, B. (1999). Technical trading rule profitability and foreign exchange intervention. Journal of International Economics, 49, 125-143. 
Liew, J. \& Vassalou M. (2000). Can book-to-market, size and momentum be risk factors that predict economic growth? Journal of Financial Economics, 57, 221-245.

Masters, M. (2008). Testimony before the committee on homeland security and governmental affairs, US Senate technical report, the $20^{\text {th }}$ of May, 2008.

Mayer, J. (2010). The Financialization of Commodity Markets and Commodity Price Volatility, UNCTAD the Financial and Economic Crisis of 2008-2009 and Developing Countries report (73-96). available at: http://www.ie.ufrj.br/hpp/intranet/pdfs/mayer_j_the_financialization_of_commodity_markets_and_commodi ty_price_volatility_2010.pdf, (retrieved 19 November 2014).

Miffre, J. \& Rallis, G. (2007). Momentum Strategies in Commodity Futures Markets. Journal of Banking and Finance, 31 , 1863-1886.

Neuhierl, A. \& Thompson, A. (2014). Trend Following Strategies in Commodity Markets and the Impact of Financialization. Job Market Paper, available at: http://www.kellogg.northwestern.edu/faculty/neuhierl/jmp.pdf (retrieved 30 January 2015).

Osler, C.L. (2000). Support for Resistance: Technical Analysis and Intraday Exchange Rates. Economic Policy Review, 6 , $53-65$.

Sanders, D.R., Irwin, S.H., \& Merrin, R.P. (2008). The adequacy of speculation in agricultural futures markets: Too much of a good thing? Marketing and Outlook Research Report 2008-02, Department of Agricultural and Consumer Economics, University of Illinois at Urbana-Champaign (June).

Scheeweis, T., Gupta, R., \& Remillard, J. (2008). CTA/Managed Futures Strategy Benchmarks: Performance and Review. F.J. Fabozzi, R. Fuss, \& D.G. Kaiser (eds.)The Handbook of Commodity Investing (pp. 266-310). Hoboken:Wiley.

Shefrin, H. \& Statman, M. (1985). The Disposition to Sell Winners too Early and Ride Losers too Long: Theory and Evidence. Journal of Finance, 40, $777-791$.

Shleifer, A., Summers, L.H. (1990). The noise trader approach to finance. Journal of Economic Perspectives, 4, 19-33.

Silvennolnen, A. \& Thorp, (2013). Financialization, crisis and commodity correlation dynamics. Journal of International Financial Markets, Institutions and Money, 24, 42-65.

Tang, K. \& Xiong, W. (2012). Index Investment and the Financialization of Commodities. Financial Analyst Journal, 68, 54-74.

Till, H. (2007a). Introduction to A Long-Term Perspective on Commodity Futures Returns. In H. Till \& J. Eagleeye (eds.)Intelligent Commodity Investing: New Strategies and Practical Insights for Informed Decision Makings (pp. 35-38). London: Risk Books.

Till, H. (2007b). Part I of a Long Term Perspective on Commodity Futures Returns: Review of Historical Literature. In H. Till \& J. Eagleeye (eds.)Intelligent Commodity Investing: New Strategies and Practical Insights for Informed Decision Makings (pp. 39-82). London: Risk

Books.Till, H. (2007c). Part II of a Long Term Perspective on Commodity Futures Returns: Term Structure as the Primary Driver of Returns, in H. Till \& J. Eagleeye (eds.). Intelligent Commodity Investing: New Strategies and Practical Insights for Informed Decision Makings (83-94). London: Risk Books.

Till, H. (2009). Has There Been Excessive Speculation in the US Oil Futures Markets?, EDHEC working paper, available at http://docs.edhec-risk.com/mrk/000000/Press/EDHEC-Risk_Position_Paper_Speculation_US_Oil_Futures.pdf [retrieved 12 September 2014].

Vdovenko A. (2013). Impact of Financialization on the Roll Return of Commodities. Master thesis, Tilburg University, Tilburg, available at: http://arno.uvt.nl/show.cgi?fid=130826, (retrieved 19 November 2014).

Working, H. (1949). The Theory of Price of Storage. American Economic Review, 39, 1254 - 1262.

Working, H. (1960). Speculation on Hedging Markets. Food Research Institute Studies, 2,185-220.

Zaremba, A.\& Konieczka, P. (2014). Value, Size and Momentum Across Countries. Indian Journal of Finance, 8(9), 7-31. Available at SSRN: http://ssrn.com/abstract=2375902 or http://dx.doi.org/10.2139/ssrn(retrieved 19 November 2014).

Zaremba, A. (2014b). Is Financialization Killing Commodity Investments? Working paper, available at SSRN: http://ssrn.com/abstract=2349903 or http://dx.doi.org/10.2139/ssrn.2349903(retrieved 19 November 2014).

Zaremba, A. (2014a), Inflation, Business Cycles, and Commodity Investing in Financialized Markets. Working paper, available at SSRN: http://ssrn.com/abstract=2389297 or http://dx.doi.org/10.2139/ssrn.2389297(retrieved 19 November 2014). 